\title{
The Effectiveness of The Mobile Learning Based on Project Based Learning Model to Improve Students Critical Thinking Ability
}

\author{
I Gusti Ayu Agung Sinta Diarini ${ }^{1}$, I Wayan Suryanto ${ }^{2}$ \\ \{gungsinta@undhirabali.ac.id ${ }^{1}$, suryanto@undhirabali.ac.id ${ }^{2}$ \} \\ Dhyana Pura University, Denpasar, Indonesia
}

\begin{abstract}
The Covid-19 pandemic has made the learning system change drastically from eye to eye gatherings to on the web learners from home. The capacity to think basically is vital for students as an important asset to succeed in life. This examination expects to decide the adequacy to improve student basic reasoning abilities. The research technique utilized is semi exploratory with a plan posttest just benchmark group plan. The sampling technique used in this investigation is a cluster random sampling technique. The data collection technique used the observation method and the distribution of questionnaires to determine the thinking students' critical skills in the subject of food processing and serving. Data analysis in this study used a statistical T-test to analize the treatment classes, namely pre-test, post-test. The outcome of the data analysis show that the application of Project-Based Learning based mobile-learning can improve student basic reasoning abilities.
\end{abstract}

Keywords Project-Based Learning, Mobile Learning, Ability Critical Thinking

\section{Introduction}

Online learning is one of the learning methods recommended by the government to limit the development of the Covid-19 virus by Circular Number 4 of 2020, namely the Usage of Instructive Strategies in a Crisis for the Spread of Covid Illness (Coronavirus), dated march 24, 2020. The most basic policy that must be done in this pandemic situation is to change the way students and teachers teach and learn from home. The teacher has made various maximum efforts to maximize the web based learning measure so that the effectiveness of learning can be fulfilled to achieve learning objectives.

The use of technology and information is expected to be able to broaden students' insights with a variety of scientific digital literature to increase their insight, knowledge, and skills. Online learning with access to information that is open to all the material they are learning is freely available, and students can seek more truth about the knowledge they are learning, can choose the right information to facilitate the learning process, connective assesses that knowledge is spread across the network of connections because learning is the ability to create and maintain these connections and students become co-creators of knowledge with teachers/teaching lecturers [1]. For this reason, the learning process must be able to be designed as comfortable as possible so that learning interest can grow into a fun, meaningful habit, the spirit of work is maintained by providing clear and structured instructions, according to the conditions of students in general without losing the essence of learning. 
The effectiveness of online learning must continue to be developed with an interesting process to be able to increase the competence of students in each subject [2]. In his opinion that the learning outcomes of students using e-learning are more effective than using the lecture method, this happens because e-learning learning is carried out anywhere and anytime. With a good understanding and increased learning motivation, the learning outcomes obtained by students will increase. Firman and Rahman stated, web based learning has adaptability in its execution and can energize free learning and inspiration to be more dynamic in learning [3]. Distance learning empowers the rise of social separating conduct and limits the presence of understudy swarms with the goal that it tends to be considered to decrease the potential for the spread of Coronavirus. With online learning, the teacher makes it easier to provide material to students by providing links or sites that are relevant to the subject being discussed so that it can be discussed together as lesson material [4]. Argues that increased skills furthermore, force in utilizing e-learning methodologies, the consideration of educators to the companion climate of student, particularly in collaboration and rivalry among student, and keenness of student in associating and building up great and sound participation in the scholastic field with their friends are things which are vital in improving understudy accomplishment.

The learning process online at SMK PGRI I Badung with limitations learning tools online such as a computer or smartphone, internet quota is limited, the signal uneven student residence and, the ability to use technology that is uneven from teachers and students is a fundamental problem that still needs to be addressed. In addition to the mastery of competence from the cognitive aspect and the effective aspect of mastery of the psychomotor aspects, efforts are made to be balanced and evenly distributed with other competencies by presenting project-based learning in practical activities in the laboratory. The policy of learning from home does not allow students to work on projects with different facilities and infrastructure such as in schools. Research Cahyaningsih et al. shows that the regular technique (vis-à-vis) is as yet viewed as better by the understudies of the e-learning since it is more obvious the material and simpler to likewise cooperate with instructors [5]. Hikmat et al. stated that online learning with Zoom and WhatsApp is only effective for theory courses, whereas in practice courses and online lecture courses are less effective [6]. Based on the outcome these studies researchers interested in conducting research Effectiveness of Learning project-based learning oriented-based products with a mobile-learning To Improve Critical Thinking Skills In SMK PGRI I Badung nature carries learn from home by using a smartphone connected to the Internet network to improve critical thinking skills when accessing information and teaching materials with a data search engine (searching) without any intervention from other parties.

\section{Literature Review}

In practice, online learning needs the help of cell phones, for example, cell phones, tablets, and workstations which can be utilized to get to data anyplace and whenever [7]. The rapid development of mobile applications with worldwide popularity has contributed greatly to the life and the learning process. For example, it offers numerous chances, just as difficulties, to plan a brilliant "versatile instructional method" with an emphasis on understudy focused learning [8], helping to implement learning models to improve learning outcomes [9] and students perceive the use of mobile devices as a positive process [10]. Mobile-Learning is an alternative learning model from home that is often used by teachers during a pandemic, students, 
most of whom already have smartphones, quickly learn to adjust to the learning being carried out.

Project-Based Learning ( Project-Based Learning - PPA ) is a learning strategy that employments a project/activity as a medium. Students believe that hard work in doing Project Based Learning assignments will get satisfaction and appreciation. Students feel lucky to be involved in learning with this curriculum and it is very unfortunate if they cannot participate in it [11]. Educators by and large report that partaking in $\mathrm{PjBL}$ assists their understudies with acquiring abilities and qualities, for example, coordinated effort and collaboration, basic reasoning and critical thinking, inventiveness and development, self-heading, and relational abilities [12]. JPL is an inside and out examination of a genuine theme, this will be significant for the consideration and endeavors of understudies. In this examination the means of an undertaking based learning model are as follows:

Table 1. Syntax for Project Based Learning Model (PjBL)

\begin{tabular}{|c|c|}
\hline Learning steps & Lecturer activities \\
\hline $\begin{array}{l}\text { Stage } 1 \\
\text { Define basic } \\
\text { questions }\end{array}$ & $\begin{array}{l}\text { Explain learning objectives, motivate students, create and determine basic } \\
\text { questions that must be discussed through mobile-learning based learning }\end{array}$ \\
\hline $\begin{array}{l}\text { Stage } 2 \\
\text { Create a project } \\
\text { design }\end{array}$ & $\begin{array}{l}\text { Facilitating students; make, determine product design by compiling careful } \\
\text { planning. (the guidance process is carried out online based on mobile-learning ) }\end{array}$ \\
\hline $\begin{array}{l}\text { Stage } 3 \\
\text { compiles a } \\
\text { schedule }\end{array}$ & $\begin{array}{l}\text { Helping students plan to schedule in prepare work with the guidance of online- } \\
\text { based mobile-learning and validate implementation schedule }\end{array}$ \\
\hline $\begin{array}{l}\text { Stage } 4 \\
\text { Monitoring } \\
\text { progress project } \\
\text { Stage } 5\end{array}$ & $\begin{array}{l}\text { Monitor the implementation of activities, progress is on schedule, and } \\
\text { verification of data following the plans made, observing the progress of the } \\
\text { learning process is online }\end{array}$ \\
\hline $\begin{array}{l}\text { Assessment of the } \\
\text { outcomes of the }\end{array}$ & Assessment and provide reinforcement of the process and student work \\
\hline $\begin{array}{l}\text { Stage } 6 \\
\text { Evaluation of } \\
\text { experience }\end{array}$ & $\begin{array}{l}\text { Conduct a thorough evaluation of student work from planning, processes and } \\
\text { work results as well as evaluation of aspects of online learning based on mobile- } \\
\text { learning }\end{array}$ \\
\hline
\end{tabular}

Critical thinking is a rational response to questions that cannot be answered with certainty and for which all the relevant information may be available. Is reasoned thinking, reflective that focuses on efforts to determine what to believe and do [13]. Indicator of basic intuition abilities in this examination are According to Ennis [13] that includes five groups thinking skills, which contains twelve indicators as presented in Table 2, namely:

Table 2. Indicators of Critical Thinking Ability

\begin{tabular}{lll}
\hline \multicolumn{1}{c}{ Ability Thinking } & \multicolumn{1}{c}{ Indicators } \\
\hline \multirow{3}{*}{ Basic clarification } & 1. focuses on questions \\
& 2. analyzing arguments \\
Basic Support & 3. ask and answer clear and challenging questions \\
& 5. assessing the credibility of sources \\
Concluding & 6. deducing and assessing reports of observations \\
& 7. inducing and assessing inducing and assessing \\
Advanced Clarification & 8. values making judgments \\
& 9. defining terms and assessing definitions
\end{tabular}




\section{Method}

The strategy utilized is semi trial with plan posttest just benchmark group configuration, inspecting method in this examination is to use techniques cluster random sampling. Data collection techniques using observation methods and questionnaire distribution to determine students' basic speculation abilities in the subject of food processing and presentation. This study aims to determine the effectiveness of the application of the mobile-learning based Project Based Learning model to improve student basic reasoning abilities. Information investigation in this examination utilized factual strategies t-test (t-test). T-test was utilized to look at the treatment classes, in particular, pre-test and post-test. by arranging the information at that point changed over into the PAP transformation rules underneath:

Table 3. Assessment Criteria

\begin{tabular}{ccll}
\hline No & Percentage $(\boldsymbol{\%})$ & Criteria for critical thinking ability \\
\hline 1 & $0-39.9$ & Very less & \\
2 & $40.0-54.9$ & Less & \\
3 & $55.0-69,9$ & Enough & \\
4 & $70.0-84.0$ & Good & Source: Santyasa [14] \\
5 & $85.0-100$ & Very good &
\end{tabular}

\section{Research Outcomes and Discussion}

Learning model This new mobile-learning-based learning model has been applied for the first time in this school following the government's appeal to limit the transmission of the COVID-19 virus. The results of the data analysis of students' critical abilities in the experimental class showed good development, the effectiveness of the project-based learning model by boldly providing new experiences to all students. The results of the evaluation of students' critical thinking in cycle I or in the pre-test stage are in a good category. There are several problems found in the learning process that requires improved planning for the implementation of learning in cycle II or the post-test phase. Basic speculation abilities in cycle II or at the test stage are in the excellent class. For more clearly evaluation and evaluation in the table 4.

Table 4. Overall Data Analysis

\begin{tabular}{lccc}
\hline \multicolumn{4}{c}{ Table 4. Overall Data Analysis } \\
\hline Highest & score lowest & score Average \\
\hline pretest score & 64 & 44 & 56 \\
Post & 99 & 81 & 90 \\
\hline
\end{tabular}

Data presentation of students' critical thinking abilities on each aspect of the indicators studied in the pre-test and the post-test is presented in the following table:

Table 5. Analysis of Data per Aspect of Critical Thinking 


\begin{tabular}{clcc}
\hline No & An aspect of Critical Thinking & Pretest Score Posttest & Score \\
\hline 1 & Basic Clarification & 60 & 88 \\
2 & Basic Support & 50 & 86 \\
3 & Summing up & 57 & 91 \\
4 & Further clarification & 51 & 93 \\
5 & Strategies and Tactics & 58 & 92 \\
\hline
\end{tabular}

Based on the calculation of the normality test, it is used to determine the results of research in classes with normal distribution or not. The normality test with a significant level is above 0.05 means that it is normally distributed. In this case, the data is normally distributed; it can be seen following table 6

Table 6. Normality Test of

\begin{tabular}{llllllc}
\hline \multirow{2}{*}{ Group } & \multicolumn{3}{l}{ Kolmogorov-Smirnov } & \multicolumn{3}{c}{ Shapiro Wilk } \\
\cline { 2 - 7 } & Statistic & df & Sig. & Statistics & df & Sig. \\
\hline Pre-test & 0.130 & 35 & 0.200 & 0.966 & 35 & 0.335 \\
Post-test & 0.132 & 35 & 0.128 & 0.958 & 35 & 0.203 \\
\hline
\end{tabular}

Next homogeneity of variance test is performed to determine whether the sample group has the same variance or not. The significance level of the variance homogeneity test is 0.05 which means the variance is homogeneous. The results of the research can be presented in table 7 .

Table 7. Homogeneity Test of

\begin{tabular}{lcccc}
\hline & Levene's Statistic & df1 & df2 & Sig. \\
\hline Pretest Posttest & 0.001 & 1 & 68 & 0.980 \\
\hline
\end{tabular}

Next, an independent sample T-test was carried out which aims to compare the means of the two paired groups, namely as follows: 1). the null hypothesis (H0): there is no significant difference in critical thinking skills between before being taught with a project-based learning model and after being taught with a project-based learning model. 2). the alternative hypothesis (Ha): there is a significant difference in critical thinking skills between before being taught with a project-based learning model and after being taught with a project-based learning model. Research results can be presented in table 8

Table 8. Dependent Sample T-Test

\begin{tabular}{|c|c|c|c|c|c|c|c|c|}
\hline & \multicolumn{5}{|c|}{ Paired Differences } & \multirow{3}{*}{1} & \multirow{3}{*}{ df } & \multirow{3}{*}{$\begin{array}{c}\text { Sig } \\
\text { (2-tailed) }\end{array}$} \\
\hline & \multirow[t]{2}{*}{ Mean } & \multirow[t]{2}{*}{$\begin{array}{c}\text { Std. } \\
\text { Deviation }\end{array}$} & \multirow{2}{*}{$\begin{array}{c}\text { Std } \\
\text { Error } \\
\text { Mean }\end{array}$} & \multicolumn{2}{|c|}{$\begin{array}{l}\text { 95\% Confidence } \\
\text { Interval of the } \\
\text { Difference }\end{array}$} & & & \\
\hline & & & & Lower & Upper & & & \\
\hline Pair 1 & $-33,72$ & 6,74 & 1,14 & $-36,03$ & $-31,40$ & $-29,6$ & 34 & 0,001 \\
\hline
\end{tabular}

Project-based learning models based on mobile-learning are effective and can improve students' critical thinking skills. With the implementation of the learning process from home, students are free to schedule project-oriented learning activities without any pressure from other parties under the guidance of teachers in the field of study online. Project-based learning models based on mobile-learning benefit students in designing learning project designs by searching for and finding supporting material using a smartphone. The online learning process makes it easier 
for teachers to monitor and observe the progress of the student-oriented learning process because each stage of the activity is shared online and does not rule out the possibility of students getting input and corrections from friends or the wider community so that the quality of productoriented learning will be better.

\section{Conclusions}

Product-oriented learning during the pandemic has brought students closer to the problemoriented learning process in real life. Studying at home triggers the spirit of learning with all its limitations and tries to find the best solution to be able to achieve learning goals completely. Some of the factors that determine the success of include student characteristics, instructional design, understanding of support for instructors and students, teacher characteristics, technology, characteristics of language skills [15]. new knowledge that is not only oriented to books but also through peers, parents, society, the internet, teachers, organizations, and society of potential consumers who directly provide criticism and also input on their products that are posted on social media. Product-oriented blessed learning project learning based on mobilelearning has been able to arouse students' critical thinking skills in the material being studied and, able to achieve learning objectives, even though the products they produce still need to be refined due to the limited equipment and facilities at home. The results of this study dismiss the responses of research by Hikmat et al. and Cahyaningsih's et al. research which generally states that online learning is only suitable for theoretical courses whereas practical and field courses are less effective [6],[5].

\section{Suggestions}

Learning activities through mobile-learning should be structured and designed well by the teacher in the field of study following the material and learning objectives to be achieved, the learning process with a humanist approach needs to be emphasized by the teacher so that students feel the presence of the teacher in the learning process, to find the essence of knowledge that they want to shape and want to build in view of the qualities and instructing and learning competencies. The significance of advancement as combination with the climate alludes to the computerized part learning biological system of Hammond which can oblige learning styles, adaptability, and learning encounters of understudies so they can produce good emotions [16]. Teachers should be able to make learning tutorials via YouTube, google classroom, or media. Online others, as a basic foothold that can guide students in the learning process before students search and find material from other sources. Furthermore, education for the formation of character and character of students can be learned in the process of self-development at any time and anywhere in the life process.

\section{References}


[1] Belawati. 2019. Pembelajaran online. Universitas Terbuka Kementrian Riset, Teknologi, Dan Pendidikan Tinggi. Edisi 1. Cetakan 1 Agustus 2019

[2] Siti Muyaroah.2019. Efektifitas E-Learning Dengan Aplikasi Moodle Pada Mata Kuliah Penelitian Pengembangan Program Studi Teknologi Pendidikan. Jurnal Ilmiah Universitas Batanghari Jambi Volume 19, Nomor 1, Februari 2019, (Halaman 114-117) DOI 10.33087/jiubj.v19i1.567 ISSN 14118939 (Online) | ISSN 2549-4236

[3] Firman dan Sari Rahayu Rahman. 2020. Pembelajaran Online di Tengah Pandemi Covid-19. Indonesian Journal of Educational Science (IJES). Volume 02, No 02. ISSN 2622-6197 (Online). ISSN 2655-4402 (Cetak)

[4] Haikal Firmansah Anas Pratama dan Sandy Arief. 2019. Pengaruh Pemanfaatan E-Learning, Lingkungan Teman Sebaya, Dan Motivasi Belajar Terhadap Prestasi Belajar. Jurnal Pendidikan Ilmu Pengetahuan Sosial Vol. 6, No. 1, Desember 2019 Halaman: 1-12 P-Issn: 2355 - 8245 E-Issn: $2614-5480$

[5] Cindy Cahyaning Astuti1, Herlinda Maya Kumala Sari dan Nuril Lutvi Azizah 2019. Perbandingan Efektifitas Proses Pembelajaran Menggunakan Metode E-Learning Dan Konvensional. Preceeding Of The ICECRS. 2:1. doi: 10.21070/picecrs.v2i1.2395

[6] Hikmat., Endang H., Aldim., \& Irwandi. 2020. Efektivitas Pembalajaran Daring Selama Masa Pandemi Covid-19: Sebuah Survey Online. Karya Tulis Ilmiah (KTI) Masa Work From Home (WFH) Covid-19. UIN Sunan Gunung Djati Bandung Tahun 2020

[7] Gikas, J., \& Grant, M. M. (2013). Mobile computing devices in higher education: Student perspectives on learning with cellphones, smartphones \& social media. Internet and Higher Education. https://doi.org/10.1016/j.iheduc.2013.06.002

[8] Lisberh Amhang. 2020. 1 Smart Mobile Learning Activities In book: Virtual and Mobile Learning Activities in Higher Education. Education Chapter: 1Publisher: IGI Global. DOI: 10.4018/978-17998-4183-8.ch001

[9] Darmiati. 2020. Penerapan Model Pembelajaran Kuantum, Berbantuan Mobile Learning untuk Meningkatkan Hasil Belajar Seni Budaya. Journal of Education Technology. Vol. 4 (1) pp. 34-40

[10] P. Krystalll and E. Mavropoulou. 2020. French For Special Purposes And Mobile Assisted Language Learning (Mall): Learners' Perspectives. Proceedings of INTED2020 Conference 2nd-4th March 2020, Valencia, Spain. ISBN: 978-84-09-17939-8

[11] Virtue, E. E. , \& Hinnant-Crawford, B. N. (2019). "We're doing things that are meaningful": Student Perspectives of Project-based Learning across the Disciplines. Interdisciplinary Journal of ProblemBased Learning, 13(2). Available at: https://doi.org/10.7771/1541-5015.1809

[12] Culclasure, B. T. , Longest, K. C. , \& Terry, T. M. (2019). Project-Based Learning (Pjbl) in Three Southeastern Public Schools: Academic, Behavioral, and Social-Emotional Outcomes. Interdisciplinary Journal of Problem-Based Learning, 13(2). Available at: https://doi.org/10.7771/1541-5015.1842

[13] Ennis, R.H. 1985. "Goals for a Critical Thinking Curriculum" in A.L Costa (ed). Developing Minds: A Resource Book for Teaching Thinking. Alexandria: ASCD, 54-57

[14] Santyasa. 2009. Implementasi Lesson Study dalam Pembelajaran. Makalah. Disajikan dalam "Seminar Implementasi Lesson Study dalam Pembelajaran bagi Guru-Guru TK, Sekolah Dasar, dan Sekolah Menengah Pertama di Kecamatan Nusa Penida, Tanggal 24 Januari 2009, di Nusa Penida.

[15] Alberth. 2018. Critical Success Factors In Online Language Learning. Paper presented at the 57th TEFLIN International Conference (1-3 November 2010) held in Bandung, Indonesia. https://www.researchgate.net/publication/325674692

[16] Oktavian.R dan Aldya.R.F. 2020. Efektivitas Pembelajaran Daring Terintegrasi Di Era Pendidikan 4.0. Jurnal Pendidikan dan Ilmu Pengetahuan. Vol.20 No.2 Tahun 2020 e-issn 2614-0578. p-issn $1412-5889$ 